\title{
Purification and Some Properties of the Basic Lectin from Winged Bean Seeds ${ }^{\dagger}$
}

\author{
Masako Higuchi and Kazuo IwaI \\ Department of Food Science and Technology, Faculty of Agriculture, \\ Kyoto University, Sakyo-ku, Kyoto 606, Japan \\ Received June 28, 1984
}

\begin{abstract}
Winged bean basic lectin was purified by affinity chromatography on $p$-aminophenyl- $\beta$-Dgalactopyranoside bound Sepharose 4B. The purified lectin was homogeneous on polyacrylamide gel electrophoresis, isoelectric focusing, and gel filtration. The molecular weight of the lectin was $53,000 \pm 1,800$ by gel filtration, SDS-polyacrylamide gel electrophoresis gave a single component of molecular weight of 27,000 , suggesting that the lectin was a dimer. The isoelectric point was $\mathrm{pH}$ $8.62 \pm 0.17$. The basic lectin was rich in aspartic acid and threonine, and poor in sulfur-containing amino acids. The basic lectin agglutinated both trypsinized and untreated human erythrocytes; it bound highest with type $\mathrm{A}$, somewhat lower with types $\mathrm{B}$ and $\mathrm{AB}$, and negligibly with type $\mathrm{O}$ erythrocytes. Among the tested sugars, D-galactose and $\mathrm{N}$-acetyl-D-galactosamine were active in inhibiting the hemagglutination. In contrast, the determinant sugars in blood group O, such as Lfucose and $N, N^{\prime}$-diacetylchitobiose, were entirely inactive, confirming the blood group-specificity of the basic lectin. Modification of the lectin with $N$-bromosuccinimide led to a significant decrease in its hemagglutinating activity, suggesting contribution of the tryptophan residues to the activity.
\end{abstract}

Lectin is a cell-agglutinating and carbohydrate-binding protein occurring in many plants, particularly legume seeds, and also in bacteria and animals.

Winged bean (Psophocarpus tetragonolobus (L.) DC) was observed to contain a significant quantity of lectin, important in the deleterious and lethal effect of raw winged bean on rats. ${ }^{1,2}$ ) Our previous study also showed that there were two electrophoretically different lectins in winged bean seeds, called basic and acidic lectins. ${ }^{3)}$ Moreover, the basic lectin was found to agglutinate human type $\mathrm{A}$ and $\mathrm{B}$ erythrocytes strongly, but human type $\mathrm{O}$ erythrocytes negligibly, in contrast to the acidic lectin. In many cases, several lectins exist in legume seeds, which can be separated by electrophoresis $^{4)}$ and ion-exchange chromatography. ${ }^{5)}$

Winged bean lectin was first isolated by
Pueppke $^{6)}$; the lectin has an isoelectric point of 5.5 and agglutinates all three A BO types of trypsinized human erythrocytes. Appukuttan and $\mathrm{Basu}^{7)}$ subsequently isolated the lectin from winged bean which agglutinates untreated human type $\mathrm{A}, \mathrm{B}$, and $\mathrm{O}$ erythrocytes equally. These lectins may be identical with the acidic lectin found in our previous study. ${ }^{3)}$

In continuation of the study which found two lectins in winged bean seeds, we have isolated the basic lectin from winged bean and investigated its physical and chemical properties. This paper describes the purification and some properties of the basic lectin from winged bean seeds.

\section{MATERIALS AND METHODS}

Materials. Ripe seeds of winged bean (Psophocarpus tetragonolobus (L.) DC) were obtained from Thailand. 1984.

Presented at 38th General Meeting of Japanese Society of Nutrition and Food Science, Kyoto, Japan, April 30,

Abbreviations: PBS, phosphate-buffered saline (7 mM phosphate- $0.15 \mathrm{M} \mathrm{NaCl}, \mathrm{pH} 7.2$ ); SDS, sodium dodecyl sulfate; PAS, periodic acid-Schiff. 
p-Aminophenyl- $\beta$-D-galactopyranoside, $\quad p$-aminophenyl- $\alpha$-L-fucopyranoside, and $N, N^{\prime}$-diacetylchitobiose were purchased from Koch-Light Laboratories, Ltd., Sigma Chemical Co., and E-Y Laboratories, Inc., respectively. $\mathrm{CNBr}$-activated Sepharose $4 \mathrm{~B}$ and Sephadex G-100 were obtained from Pharmacia Fine Chemicals, and bovine trypsin was obtained from Difco Laboratories. All other chemicals of analytical grade were purchased from either Nakarai Chemicals, Ltd., or Wako Pure Chemical Industries, Ltd.

Purification of basic lectin from winged bean. Ion exchange chromatography of the seed extract on a DEAESephadex A-50 was performed as had been described in our previous report. ${ }^{3)}$ The bulk of the hemagglutinating activity was eluted as two peaks with a linear gradient of $\mathrm{NaCl}(0$ to $0.6 \mathrm{M})$. The first peak was dialyzed against PBS. The dialysate was put on a $p$-aminophenyl- $\beta$-D-galactopyranoside bound Sepharose $4 \mathrm{~B}$ column $(1.5 \times 8 \mathrm{~cm})$ equilibrated with PBS. The column was washed with PBS until $A_{280}$ of the effluent was below 0.02. Material which bound to the column was then eluted with $0.1 \mathrm{M}$ Dgalactose in PBS. Protein fractions monitored with $A_{280}$ were collected and dialyzed extensively against PBS. Hemagglutinating activity was determined at each step with trypsinized rabbit erythrocytes. Protein was measured by the method of Lowry et al.$^{8)}$ using bovine serum albumin as the standard.

Hemagglutinating activity. Hemagglutination test was done by a serial 2-fold dilution method in microtiter plate. ${ }^{9)}$ Trypsinized erythrocytes were prepared by treatment of a $4 \%$ cell suspension in PBS with trypsin (1 mg/ $\mathrm{ml})$ at $37^{\circ} \mathrm{C}$ for $1 \mathrm{hr}$. Each sample $(25 \mu \mathrm{l})$ was serially diluted in PBS $(25 \mu \mathrm{l})$ and a $4 \%$ suspension of trypsinized erythrocytes $(10 \mu \mathrm{l})$ was added to each well of a microtiter plate, and agglutination was determined after incubation at $37^{\circ} \mathrm{C}$ for $1 \mathrm{hr}$. A $4 \%$ suspension of trypsinized rabbit erythrocytes was routinely used for determining the hemagglutination. Hemagglutinating activity (titer) is defined as the reciprocal of the greatest dilution at which agglutination occurred.

Hemagglutination inhibition tests were performed using a concentration of the lectin that was 4 times the dilution endpoint. Sugar solution $(20 \mu \mathrm{l})$ was serially diluted with PBS $(20 \mu \mathrm{l})$ and the lectin solution $(5 \mu \mathrm{l})$ was added to each well. After $30 \mathrm{~min}$, a $4 \%$ suspension of trypsinized rabbit erythrocytes $(10 \mu \mathrm{l})$ was added to the well. The minimum amount of each tested sugar necessary to completely inhibit hemagglutination was determined after incubation at $37^{\circ} \mathrm{C}$ for $1 \mathrm{hr}$.

Polyacrylamide gel disc electrophoresis. Disc electrophoresis was carried out in a $7.5 \%$ polyacrylamide gel with acetate-KOH buffer ( $\mathrm{pH} 4.3),{ }^{10}$ to evaluate the purity of the basic lectin. Staining was performed with Coomassie brilliant blue G-250 for protein and periodic acid-Schiff
(PAS) reagent for carbohydrate. ${ }^{11)}$

SDS-polyacrylamide gel electrophoresis. SDS-polyacrylamide gel electrophoresis was done at $\mathrm{pH} 7.2$ in a $10 \%$ gel according to the method of Weber and Osborn. ${ }^{12)}$ The molecular weight of the subunit was calculated with bovine serum albumin $(67,000)$, ovalbumin $(45,000)$, trypsin $(24,000)$, myoglobin $(17,000)$, and cytochrome $c$ $(13,000)$ as standard proteins.

Isoelectric focusing. The sample solution containing $2 \%$ Ampholine (pH $3.5 \sim 10.0)$ and $30 \%$ sucrose was put on a $7.5 \%$ polyacrylamide gel containing $2 \%$ Ampholine. As anodic and cathodic electrolytes, $20 \mathrm{~mm}$ phosphoric acid and $0.8 \mathrm{M} \mathrm{NaOH}$ were employed, respectively.

Molecular weight determination. The molecular weight of the purified basic lectin was determined by gel filtration on Sephadex G-100. The standard proteins used were the same as those for the SDS-polyacrylamide gel electrophoresis.

Amino acid analysis. The lyophilized sample of the purified basic lectin was hydrolyzed with $6 \mathrm{~N} \mathrm{HCl}$ at $110^{\circ} \mathrm{C}$ for 24 and $72 \mathrm{hr}$ in sealed and evacuated tubes, ${ }^{13)}$ and analyzed with a Hitachi 835 high performance amino acid analyzer equipped with a data processor. Tryptophan was determined after hydrolysis of the lectin in $4 \mathrm{M}$ methane sulfonic acid containing $0.2 \%$ tryptamine at $115^{\circ} \mathrm{C},{ }^{14)}$ and cystine was oxidized with performic acid before hydrolysis with $6 \mathrm{~N} \mathrm{HCl}{ }^{15)}$

Effects of $p H$ on the purified basic lectin. The purified basic lectin was preincubated in buffers of different $\mathrm{pH}$ at room temperature for $1 \mathrm{hr}$, and the remaining hemagglutinating activity was determined at $\mathrm{pH} 7.2$ with the serial 2-fold dilution method. We used $0.1 \mathrm{M}$ citrate- $\mathrm{HCl}$ buffer $(\mathrm{pH} 1.8 \sim 4.0), 0.1 \mathrm{M}$ citrate- $\mathrm{NaOH}$ buffer $(\mathrm{pH}$ $5.0 \sim 6.0$ ), $0.1 \mathrm{M}$ phosphate buffer ( $\mathrm{pH} 7.0 \sim 8.0), 0.1 \mathrm{M}$ Tris$\mathrm{HCl}$ buffer $(\mathrm{pH} 8.0 \sim 9.0)$, and $0.1 \mathrm{M}$ borate buffer $(\mathrm{pH}$ $10.1 \sim 11.0)$.

Effects of temperature on the purified basic lectin. The purified lectin dissolved in PBS was incubated at various temperatures for $5 \mathrm{~min}$. After having been cooled immediately in ice-water bath, the remaining hemagglutinating activity was determined.

Chemical modifications of the purified basic lectin. The lectin solution was used at $0.1 \%$ for modification experiments. Tyrosine residues were acetylated with $1 \mathrm{~mm} N$ acetylimidazole in $0.02 \mathrm{M}$ Veronal buffer $(\mathrm{pH} 7.5)$ at room temperature for $2 \mathrm{hr}^{16)}$ Lysine residues were modified with $0.64 \mathrm{M} o$-methylisourea ${ }^{17)}$ in $\mathrm{NaOH}(\mathrm{pH} 10.5)$ at $4^{\circ} \mathrm{C}$ for 7 days. Arginine modification was done with $0.05 \mathrm{M} \mathrm{1,2-}$ cyclohexanedione in $0.25 \mathrm{M}$ borate buffer $(\mathrm{pH} 9.0)$ at $37^{\circ} \mathrm{C}$ for $2 \mathrm{hr}^{18)}$ Modification of tryptophan residues with 
Table I. Purification of Basic Lectin from Winged Bean

\begin{tabular}{|c|c|c|c|c|c|}
\hline Step & $\begin{array}{l}\text { Total protein } \\
(\mathrm{mg})\end{array}$ & $\begin{array}{l}\text { Total activity }{ }^{a} \\
\quad \text { (titer) }\end{array}$ & $\begin{array}{c}\text { Specific activity } \\
\text { (titer/mg protein/ml) }\end{array}$ & $\begin{array}{l}\text { Yield } \\
(\%)\end{array}$ & Fold \\
\hline Crude extract ${ }^{b}$ & 1574.4 & $256^{\times 10^{3}}$ & 163 & 100 & - \\
\hline $\begin{array}{l}\text { First fraction }{ }^{c} \text { on } \\
\text { DEAE-Sephadex A-50 }\end{array}$ & 87.0 & 163 & 1874 & 63.7 & 11.5 \\
\hline $\begin{array}{l}0.1 \text { M D-galactose elute } \\
\text { from affinity column }\end{array}$ & 16.4 & 147 & 8963 & 57.4 & 55.0 \\
\hline
\end{tabular}

a Hemagglutinating activity was determined by the serial 2 -fold dilution method using a $4 \%$ suspension of trypsinized rabbit erythrocytes.

b Extracted from $6 \mathrm{~g}$ of winged bean seeds with 10 volumes of $7 \mathrm{~mm}$ phosphate buffer ( $\mathrm{pH} 7.2$ ).

c Eluted immediately after initiation of washing of the column.

${ }^{d} p$-Aminophenyl- $\beta$-D-galactopyranoside bound Sepharose 4B column.

$0.01 \mathrm{M} N$-bromosuccinimide was done in $0.1 \mathrm{M}$ citrate buffer ( $\mathrm{pH}$ 6.0) at room temperature according to Spande and Witkop. ${ }^{19)}$ Amino groups were modified with $2.8 \mathrm{~mm}$ trinitrobenzenesulfonic acid in $0.2 \mathrm{M}$ borate buffer ( $\mathrm{pH} 9.2$ ) at $40^{\circ} \mathrm{C}$ for $2 \mathrm{hr}^{20)}$ Modification of carboxyl groups was done with $15.8 \mathrm{~mm} \quad N$-ethyl-5-phenylisoxazolium-3'sulfonate (Woodwards $\mathrm{K}$ reagent) in $0.1 \mathrm{M}$ citrate buffer (pH 3.8) for 30 min. $^{21)}$ After each treatment, all modified samples were dialyzed extensively against PBS. The hemagglutinating activity was then determined with the serial 2-fold dilution method, and the protein concentration was calculated by amino acid analyses. Amounts of the modified residues were determined spectrophotometrically and with amino acid analyses.

\section{RESULTS}

\section{Purification of basic lectin from winged bean}

Table I summarizes a typical purification of basic lectin from winged bean. The first fraction on DEAE-Sephadex chromatography, in which about $64 \%$ of the original activity was recovered, was further purified by adsorption to $p$-aminophenyl- $\beta$-D-galactopyranoside bound Sepharose 4B and elution with $0.1 \mathrm{M} \mathrm{D-}$ galactose. The recovery of the activity put on the affinity column was about $90 \%$. The final preparation yielded about $16 \mathrm{mg}$ of the basic lectin per $6 \mathrm{~g}$ of raw winged bean seeds which agglutinated trypsinized rabbit erythrocytes at a concentration of $0.1 \sim 0.2 \mu \mathrm{g} / \mathrm{ml}$. About $150 \mathrm{mg}$ of the lectin was obtained by repetition of the purification procedure and used for experiments.

\section{Homogeneity of the purified basic lectin}

Homogeneity of the purified basic lectin was

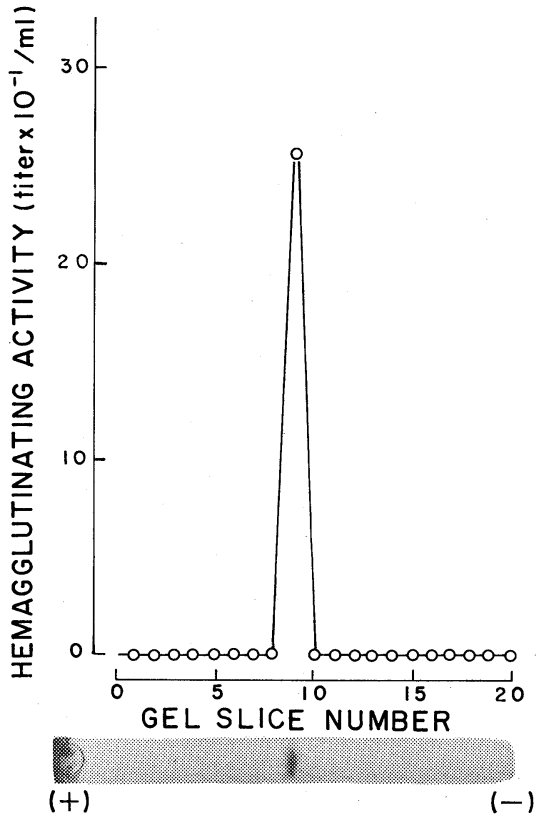

FIG. 1. Polyacrylamide Gel Disc Electrophoresis of the Purified Basic Lectin.

The purified lectin $(20 \mu \mathrm{g})$ was subjected to electrophoresis in a $7.5 \%$ acrylamide gel at $\mathrm{pH} 4.3$ for $2 \mathrm{hr}$ at $5 \mathrm{~mA} /$ tube. After the electrophoresis a gel was stained with Coomassie brilliant blue G-250, and an unstained gel was cut into $4 \mathrm{~mm}$ slices for an assay of the hemagglutinating activity (O). The direction of migration was from the anode to the cathode.

shown by disc electrophoresis (Fig. 1), SDSpolyacrylamide gel electrophoresis (Fig. 2), isoelectric focusing (Fig. 3), and gel filtration.

Disc electrophoresis of the purified basic lectin at $\mathrm{pH} 4.3$ gave a single protein band, as 


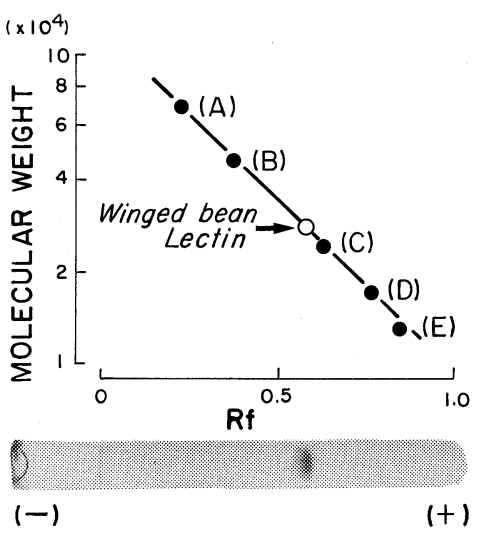

FIG. 2. SDS-Polyacrylamide Gel Elecrophoresis of the Purified Basic Lectin.

The purified lectin $(20 \mu \mathrm{g})$ was heated at $80^{\circ} \mathrm{C}$ for $30 \mathrm{~min}$ in $10 \mathrm{~mm}$ phosphate buffer ( $\mathrm{pH} 7.2$ ) containing $1 \% \mathrm{SDS}, 10 \%$ 2-mercaptoethanol, and $20 \%$ glycerol, and then subjected to electrophoresis for $3 \mathrm{hr}$ at $8 \mathrm{~mA} /$ tube in a $10 \%$ acrylamide gel $\mathrm{A}$ gel was stained with Coomassie brilliant blue G-250, and molecular weight was estimated by comparison with standard proteins. (A), bovine serum albumin; (B), ovalbumin; (C), trypsin; (D), myoglobin; (E), cytochrome $c$. The direction of migration was from the cathode to the anode.

shown in Fig. 1. The hemagglutinating activity was detected in a single segment of the unstained gel corresponding with the protein band. Since the purified basic lectin was stained with PAS reagent as well as Coomassie brilliant blue G-250, it was suggested to be a glycoprotein.

Isoelectric focusing of the purified lectin showed a single protein band, and the hemagglutinating activity was confined to a single segment of the unstained gel corresponding with the protein band (Fig. 3). The isoelectric point of the lectin was estimated to be $8.62 \pm 0.17$ as average of 8 determinations.

\section{Estimation of molecular weight}

The molecular weight of the purified basic lectin was determined by gel filtration on Sephadex G-100 to be $53,000 \pm 1,800$. SDSpolyacrylamide gel electrophoresis of the purified lectin gave a single band, as shown in Fig. 2. The molecular weight of the subunit was calculated to be $27,000 \pm 1,600$ from the

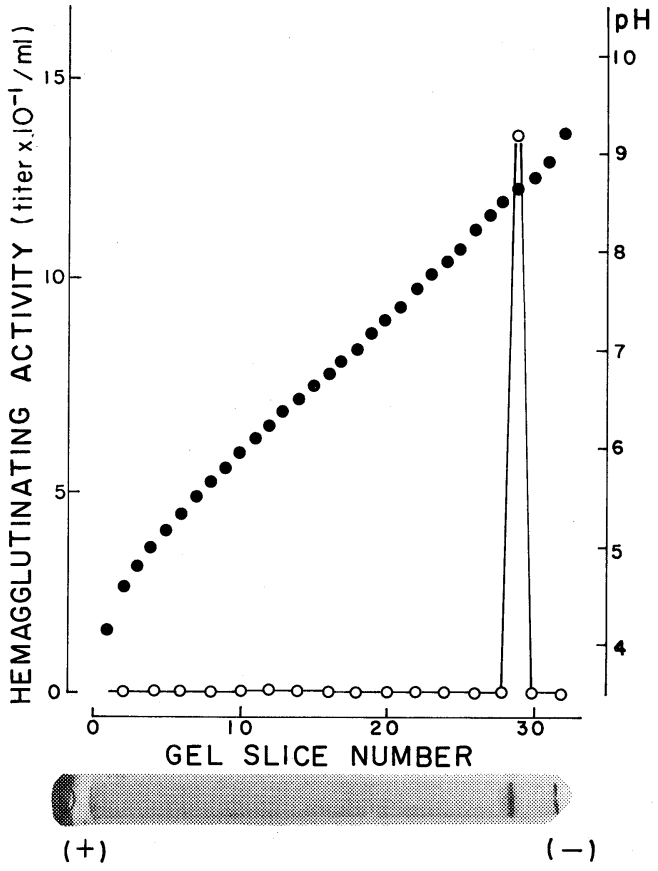

FIG. 3. Isoelectric Focusing of the Purified Basic Lectin.

The purified basic lectin $(10 \mu \mathrm{g})$ was put on a $7.5 \%$ polyacrylamide gel containing $2 \%$ Ampholine $(\mathrm{pH} 3.5 \sim$ 10.0). Electrophoresis was done with the first voltage $(100 \mathrm{~V})$ for $1 \mathrm{hr}$ and then at a constant voltage $(200 \mathrm{~V})$ for $5 \mathrm{hr}$ at $4^{\circ} \mathrm{C}$. After electrophoresis, a gel was stained with Coomassie brilliant blue G-250. An unstained gel was cut into $3 \mathrm{~mm}$ slices for the hemagglutinating activity assay (O) and $\mathrm{pH}$ determination $(\mathbf{O})$. The direction of $\mathrm{mi}-$ gration was from the anode to the cathode.

relative mobilities compared with those of the standard proteins.

\section{Amino acid composition of the purified basic lectin}

Table II shows the amino acid composition of the purified basic lectin: A high content of aspartic acid, threonine, and valine was observed. Methionine and cysine were hardly detected.

\section{Heat and $p H$ stability of the purified basic lectin}

The purified basic lectin was stable in the $\mathrm{pH}$ range $1.8 \sim 10.0$, as given in Fig. 4 . At $\mathrm{pH} 11.0$ the hemagglutinating activity of the lectin was decreased to $12.5 \%$ of the initial value.

The heat stability of the purified basic lectin 
Table II. Amino Acid Composition of the PURified BASIC LECTIN

\begin{tabular}{lcc}
\hline Amino acid & \\
\hline Lysine & Residues $/ \mathrm{mol}^{b}$ & Nearest integer \\
Histidine & 20.1 & 20 \\
Arginine & 8.4 & 8 \\
Aspartic acid & 16.3 & 16 \\
Threonine & 53.9 & 54 \\
Serine & 40.2 & 40 \\
Glutamic acid & 38.3 & 38 \\
Proline & 38.2 & 38 \\
Glycine & 36.0 & 36 \\
Alanine & 36.4 & 36 \\
Cystine & 31.9 & 32 \\
Valine & 0.3 & 0 \\
Methionine & 40.4 & 40 \\
Isoleucine & 0.4 & 0 \\
Leucine & 31.7 & 32 \\
Tyrosine & 31.6 & 32 \\
Phenylalanine & 10.4 & 10 \\
Tryptophan & 29.5 & 30 \\
Total & 4.2 & 4 \\
\hline
\end{tabular}

a Amino acids were analyzed with a Hitachi 835 high performance amino acid analyzer. The amounts are average from 24 and $72 \mathrm{hr}$ hydrolyses. Values for serine and threonine were obtained by extrapolation to zero time, and maximum values were taken for valine and isoleucine. Tryptophan was determined after hydrolysis in $4 \mathrm{M}$ methane sulfonic acid containing $0.2 \%$ tryptamine at $115^{\circ} \mathrm{C}$ for $22 \mathrm{hr}$.

$b$ Based on the calculation that the molecular weight was 53,000 .

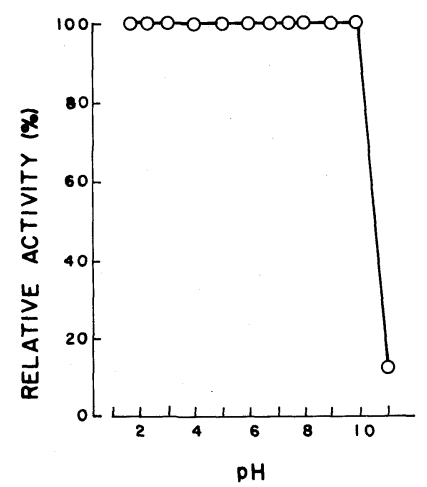

FIG. 4. Stability at Different $\mathrm{pH}$ of the Purified Basic Lectin.

The purified lectin $(0.5 \mathrm{mg})$ was preincubated in buffers $(0.25 \mathrm{ml})$ with different $\mathrm{pH}(\mathrm{pH} 1.8$ to 11.0$)$ for $1 \mathrm{hr}$ at room temperature and the remaining activity was determined at pH 7.2 in PBS $(2.25 \mathrm{ml})$ by the serial 2-fold dilution method.
Table III. Agglutination of ERythrocytes by the Purified Basic Lectin

\begin{tabular}{cc}
\hline Erythrocytes source $^{a}$ & Relative activity $^{b}$ \\
\hline Human & \\
Type A & 100 \\
Type B & 50 \\
Type AB & 50 \\
Type O & 0.2 \\
Rabbit & 50 \\
Rat & 0.8 \\
Sheep & No agglutination \\
Swine & 0.8 \\
Cattle & 6.3 \\
\hline These erythrocytes were trypsinized at $37^{\circ} \mathrm{C}$ for $1 \mathrm{hr}$. \\
The hemagglutinating activity with human type A \\
Thythrocytes was taken as 100.
\end{tabular}

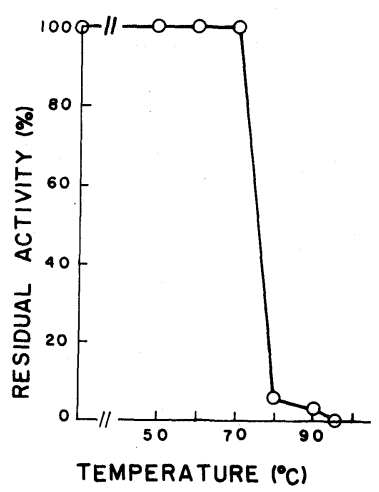

FIG. 5. Effects of Temperature on the Purified Basic Lectin.

The purified basic lectin $(0.2 \mathrm{mg})$ dissolved in PBS (1 ml) was incubated at various temperatures for $5 \mathrm{~min}$. After having been cooled immediately in an ice-water bath, the remaining activity was determined by the serial 2fold dilution method.

was examined by heating at various temperatures for $5 \mathrm{~min}$ (Fig. 5). At $70^{\circ} \mathrm{C}$ the hemagglutinating activity of the basic lectin in PBS (pH 7.2) was stable for $5 \mathrm{~min}$, but was decreased to half its initial value by heating for $1 \mathrm{hr}$. Above $80^{\circ} \mathrm{C}$ the activity was lowered rapidly, and was completely lost at $95^{\circ} \mathrm{C}$ after $5 \mathrm{~min}$.

\section{Blood group-specific agglutination}

The purified basic lectin agglutinated trypsinized human and several animal erythro- 
TABle IV. Inhibition of Hemagglutinating ACtivity of The Purified Basic LeCTIN BY VARIOUS SUGars

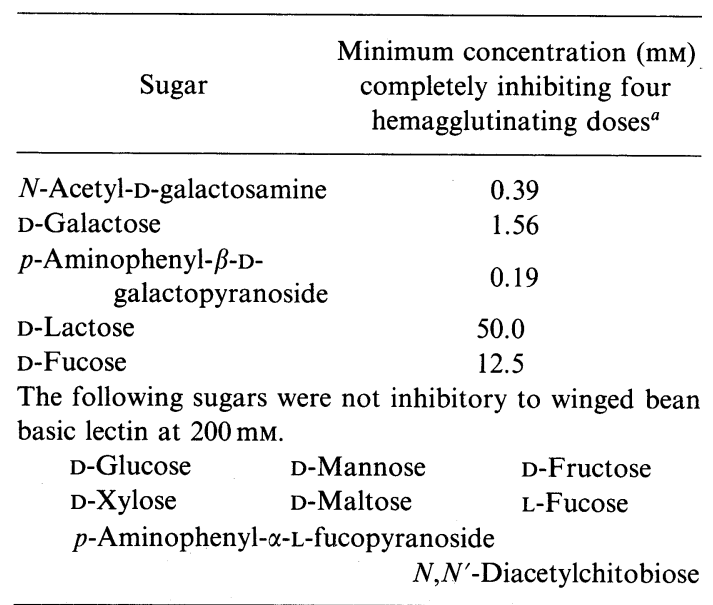

a Hemagglutination inhibition tests were performed using a concentration of the basic lectin that was 4 times above the dilution endpoint and a $4 \%$ suspension of trypsinized rabbit erythrocytes. Experimental details are shown in Materials AND Methods.

Table V. Chemical Modifications of the Purified Basic Lectin by Various Reagents

\begin{tabular}{|c|c|c|c|}
\hline Reagent & \multicolumn{2}{|c|}{$\begin{array}{l}\text { Modified residue } \\
\text { ( } \mathrm{mol} / \mathrm{mol} \\
\text { of lectin) }\end{array}$} & \multirow{2}{*}{$\begin{array}{c}\begin{array}{c}\text { Relative } \\
\text { activity }^{a} \\
(\%)\end{array} \\
100\end{array}$} \\
\hline$N$-Acetylimidazole & Tyr & 3.8 & \\
\hline$O$-Methylisourea & Lys & 18.4 & 100 \\
\hline 1,2-Cyclohexane dione & Arg & 2.4 & 100 \\
\hline$N$-Bromosuccinimide & Trp & 2.1 & 0.4 \\
\hline $\begin{array}{l}\text { Trinitrobenzenesulfonic } \\
\text { acid }\end{array}$ & $-\mathrm{NH}_{2}$ & 19.3 & 100 \\
\hline $\begin{array}{l}N \text {-Ethyl-5-phenyliso- } \\
\text { xazolium- } 3 \text { '-sulfonate } \\
\text { (Woodwards } \mathrm{K} \text { reagent) }\end{array}$ & $-\mathrm{COOH}$ & 5.8 & 100 \\
\hline
\end{tabular}

a The hemagglutinating activity in the control experiment, which was performed in parallel, was taken as 100 .

cytes but not the sheep's (Table III). The basic lectin also agglutinated untreated rabbit and human erythrocytes, except type $\mathrm{O}$ blood. Treatmant of the erythrocytes with trypsin enhanced the sensitivity of the agglutinating reaction.

\section{Inhibition of agglutination by sugars}

Table IV shows inhibition of the agglutinat- ing activity of the purified basic lectin by sugars. Among the tested sugars, $p$ aminophenyl- $\beta$-D-galactopyranoside was the best inhibitor, causing $100 \%$ inhibition of agglutination at a concentration of $0.19 \mathrm{~mm}$. The activity was effectively inhibited by $N$-acetyl-Dgalactosamine, a sugar known to be closely related to the anti-A agglutinin, ${ }^{22)}$ less by $\mathrm{D}$ galactose, and least by $\mathrm{D}$-lactose. The agglutination of the lectin was not inhibited even at a concentration of $200 \mathrm{~mm}$ by either L-fucose or $N, N^{\prime}$-diacetylchitobiose, which have been reported to be determinant sugars in blood group $\mathrm{O} .^{23,24)}$

\section{Chemical modifications of the purified basic lectin}

Table V summarizes the effect of chemical modifications on the hemagglutinating activity of the basic lectin. Modification of the lectin with $N$-bromosuccinimide resulted in a significant decrease in the hemagglutinating activity and also in oxidation of $2 \mathrm{~mol}$ of tryptophan residues per molecule. In contrast, no significant change of the hemagglutinating activity was observed in modification of tyrosine, lysine, arginine, amino groups, and carboxyl groups of the lectin. As to amino groups, respective amounts of modified $\alpha$ - and $\varepsilon$-amino groups could not be determined, because both types of amino groups react with trinitrobenzenesulfonic acid.

\section{DISCUSSION}

Our previous study found two distinct lectins in winged bean seeds; they differ from each other both electrophoretically (basic and acidic) and in agglutinating specificity. ${ }^{3)}$

In this study, following DEAE-Sephadex chromatography, the basic lectin was purified by specific adsorption to $p$-aminophenyl- $\beta$-Dgalactopyranoside bound Sepharose $4 \mathrm{~B}$ and elution with D-galactose (Table I); it was shown to be electrophoretically homogeneous (Figs. 1 3). Molecular weight of the purified basic lectin was $53,000 \pm 1,800$, and that of the subunit was $27,000 \pm 1,600$. Thus, the purified 
basic lectin was suggested to be a dimer. The purified basic lectin was stable over a wide $\mathrm{pH}$ range (Fig. 4) and active below $70^{\circ} \mathrm{C}$ (Fig. 5).

Concerning the amino acid composition, the purified basic lectin appeared to be similar to most other purified lectins, being rich in acidic amino acids and poor in the sulfur-containing amino acids (Table II).

Both blood group-specific and -nonspecific lectins have been shown to exist together in some plants, such as Phaseolus vulgaris ${ }^{25)}$ and Vicia cracca. $^{26)}$ An interesting characteristic of the purified winged bean basic lectin was found in its blood group-specificity; the hemagglutinating activity toward human type $\mathrm{O}$ erythrocytes was negligible (Table III). As to the acidic lectin coexisting in winged bean, it has been observed that its activity toward human type $\mathrm{O}$ erythrocytes is markedly stronger than that of the basic lectin. ${ }^{3}$ )

During the preparation of this paper, $\mathrm{Kortt}^{27)}$ reported the isolation and some properties of three basic lectins (B1, B2, and B3) from winged bean seeds. He indicated that isoelectric points of these lectins were higher than $\mathrm{pH}$ 9.5. In contrast, the basic lectin purified in the present study gave a single band corresponding with $\mathrm{pH} 8.62$ (Fig. 3). Although the isoelectric point of each purified lectin was not determined in his paper, ${ }^{27)}$ lectin B1 may be suspected to be identical with the basic lectin purified in our study, judging from the picture of his gel. A notable similarity exist between his lectin B1 and our lectin in their (a) almost identical molecular weight, (b) similar amino acid composition, (c) identical human blood type specificity, and (d) identical inhibition by the same sugars. Kortt ${ }^{27)}$ obtained two more lectins (B2 and B3) which have higher isoelectric points than that of the lectin $\mathrm{B} 1$, whereas we could isolate only a single basic lectin. Further study is needed to reveal their differences. A possible explanation, however, would be that the properties of the lectins from different legume seed materials might also differ. The major seed proteins, including lectins, have been reported to differ significantly from each other in their physi- cochemical properties and quantities when they are obtained from different bean cultivars. $^{28,29)}$

Modification of the purified basic lectin with $\mathrm{N}$-bromosuccinimide caused a strong decrease in the hemagglutinating activity (Table V). The decrease of the acivity could be either due to a conformational change of the protein or the chemical modification of the indole ring of the tryptophan residues. Since addition of $N$ bromosuccinimide to the purified basic lectin showed a decrease in the absorbance at $280 \mathrm{~nm}$, the tryptophan residues might be transformed to their oxindole derivatives. ${ }^{19)}$ In fact, 2 mol of tryptophan out of the original 4 residues were oxidized with $N$-bromosuccinimide. These results suggest that tryptophan residues may be responsible for the hemagglutinating activity of the lectin. Participation of tryptophan residues in the hemagglutinating activity has been reported for other lectins, such as wheat germ lectin, ${ }^{30}$ ) pea lectin ${ }^{31)}$ and potato lectin. ${ }^{32)}$ Additional chemical modification studies including oxidation with varying amounts of $\mathrm{N}$-bromosuccinimide are now in progress.

Acknowledgment. We are grateful to Mrs. M. Matsubara, née Suga, Mr. I. Tsuchiya, and Mr. K. Inoue for their helpful collaborations.

\section{REFERENCES}

1) M. Higuchi, M. Suga and K. Iwai, Agric. Biol. Chem., 47, 1879 (1983).

2) M. Higuchi, I. Tsuchiya and K. Iwai, Agric. Biol. Chem., 48, 695 (1984).

3) M. Higuchi, K. Inoue and K. Iwai, Agric. Biol. Chem., 48, 2177 (1984).

4) I. K. Howard, H. J. Sage, and M. D. Stein, J. Biol. Chem., 246, 1590 (1971).

5) T. Takahashi, P. Ramachandramurthy and I. E. Liener, Biochim. Biophys. Acta, 133, 123 (1967).

6) S. G. Pueppke, Biochim. Biophys. Acta, 581, 63 (1979).

7) P. S. Appukuttan and D. Basu, Anal. Biochem., 113, 253 (1981).

8) O. H. Lowry, N. J. Rosebrough, A. L. Farr and R. J. Randall, J. Biol. Chem., 193, 265 (1951).

9) T. K. Gartner, J. M. Gerrard, J. G. White and D. C. Williams, Nature, 289, 688 (1981).

10) R. A. Reisfeld, U. J. Lewis, D. E. Williams, Nature, 
195, 281 (1962)

11) R. M. Zacharius, T. E. Zell, J. H. Morrison and J. J. Woodlock, Anal. Biochem., 30, 148 (1969).

12) K. Weber and M. Osborn, J. Biol. Chem., 244, 4406 (1969).

13) D. H. Spackman, W. H. Stein and S. Moore, Anal. Chem., 30, 1190 (1958).

14) R. J. Simpson, M. R. Neuberger and T. Y. Liu, J. Biol. Chem., 251, 1936 (1976).

15) S. Moore, J. Biol. Chem., 238, 235 (1963).

16) J. F. Riordan and B. L. Vallee, Methods Enzymol., 11, 570 (1967).

17) J. R. Kimmel, Methods Enzymol., 11, 584 (1967).

18) L. Patthy and E. L. Smith, J. Biol. Chem., 250, 557 (1975).

19) T. F. Spande and B. Witkop, Methods Enzymol., 11, 498 (1967).

20) R. Haynes, D. T. Osuga and R. E. Feeney, Biochemistry, 6, 541 (1967).

21) G. Feinstein, P. Bodlaender and E. Shaw, Biochemistry, 8, 4949 (1969).
22) Z. Yoshizawa and T. Miki, Biochim. Biophys. Acta, 62, 180 (1962).

23) T. Osawa, Biochim. Biophys. Acta, 115, 507 (1966).

24) W. T. J. Morgan and W. M. Watkins, Brit. J. Exptl. Pathol., 34, 94 (1953).

25) G. C. Toms and T. D. Turner, J. Pharm. Pharmacol., 17, Suppl., 118 S (1965).

26) K. Aspberg, H. Holmén and J. Porath, Biochim. Biophys. Acta, 160, 116 (1968).

27) A. A. Kortt, Eur. J. Biochem., 138, 519 (1984).

28) S. Yanagi, N. Yoshida and K. Saio, Agric. Biol. Chem., 47, 2267 (1983).

29) M. L. Kakade, N. R. Simons, I. E. Liener and J. W. Lambert, J. Agr. Food Chem., 20, 87 (1972).

30) J. P. Privat, R. Lotan, P. Bouchard, N. Sharon and M. Monsigny, Eur. J. Biochem., 68, 563 (1976).

31) L. Burěs, G. Entlicher and J. Kocourek, Biochim. Biophys. Acta, 285, 235 (1972).

32) A. Jimbo, N. Seno and I. Matsumoto, J. Biochem., 95, 267 (1984). 